\title{
ANNOTATIONS ON TWO SPECIES OF LINYPHIID SPIDERS DESCRIBED BY THE LATE WILTON IVIE*
}

\author{
By P. J. van Helsdingen \\ Rijksmuseum van Natuurlijke Historie, Leiden, Netherlands
}

In December 1966 a short paper by Wilton Ivie was published in the Journal of the New York Entomological Society. In that paper the author described and illustrated two new species of Linyphiidae, Taranucnus durdenae from Pennsylvania, and Troglohyphantes ko$k o k o$, from Ontario. The latter was also recorded from the state of New York. In the course of my study of the North American Linyphiidae it appeared that both were junior synonyms of North American species, as will be discussed below. In a vast faunal region as North America such mistakes are quite understandable and not easily avoided, especially when a species originally was described in a rather ill-chosen genus, or when the older description of the species was based on the opposite sex.

While correcting the names of the two species, I take the opportunity to discuss their distributions, habitats, and affinities wherever I have something of presumed importance to add. To avoid confusion the two species will be discussed separately under their correct names.

\section{Taranucnus ornithes (Barrows) \\ Figures I-IO}

Lepthyphantes ornithes Barrows, 1940, Ohio J. Sci., 40: 134, figs. 7-7C (descr. ㅇ ô ; Ohio, Tennessee). - Vogel, 1967, Mem. Amer. Ent. Soc., 23: 93 (catal.).

Taranucnus durdenae Ivie, 1966, J. New York Ent. Soc., 74: 224, figs. 1-5 (descr. 우 ô ; Pennsylvania). - Vogel, 1967, Mem. Amer. Ent. Soc., 23: 100 (catal.). Vogel, 1968, J. New York Ent. Soc., 76: 102 (Pennsylvania). NEW SYNONYMY.

Types. - Lectotype $\sigma^{\pi}$ of Lepthyphantes ornithes, by present designation, from Sugar Grove, Ohio. There are two o paralectotypes, from Sugar Grove, Ohio, and the Great Smoky Mountains National Park, Tennessee. All three specimens are in the Barrows Collection at the Ohio State University, Columbus, Ohio, and were examined.

\footnotetext{
*Based on research done at the Museum of Comparative Zoology and published with a grant from the Museum of Comparative Zoology.

Manuscript received by the editor March 25, 1973
} 


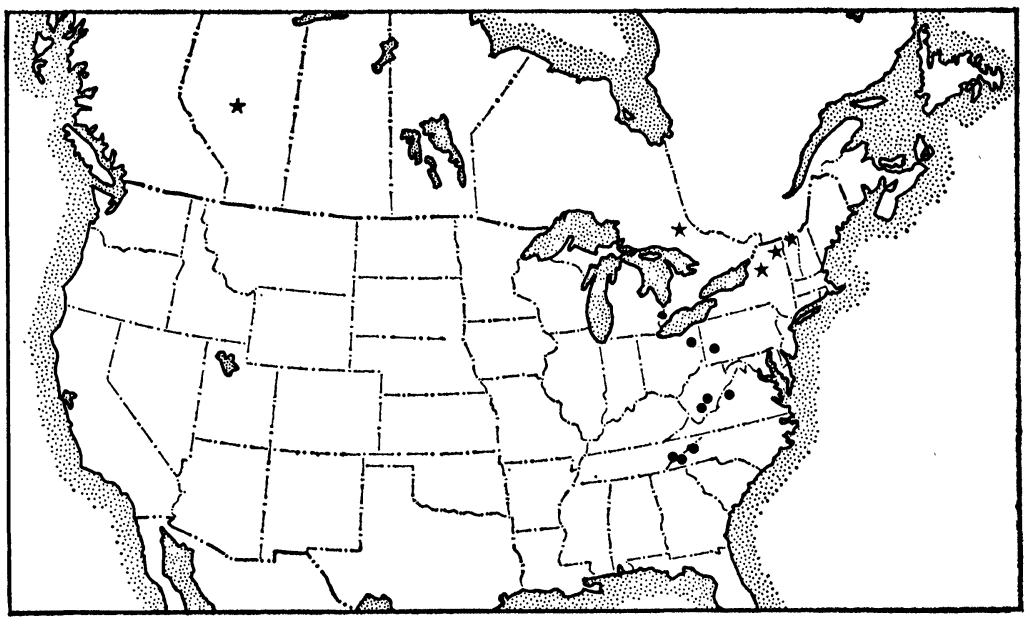

Figure 1. Map showing distributions of Taranucnus ornithes (Barrows) $(\bullet)$ and Oreonetides recurvatus (Emerton) ( $\star$ ).

The $\sigma^{t}$ holotype and $q$ paratype of Taranucnus durdenae, from Rector, Pennsylvania, should be in the American Museum of Natural History, New York, but they were not examined by me.

In the Barrows collection, through kind cooperation of Dr. C. A. Triplehorn, one vial with Lepthyphantes ornithes was located. This vial contained one $\sigma^{x}$ and two $q$ specimens, together with a label referring to the Ohio locality. A second vial, with the recorded $q$ from the Smoky Mountains, could not be found. It appears, that the single o specimen from the latter locality has been added to the Ohio material. The original description mentions one $q$ from each locality (page 134, ninth line from bottom), while now two females are present in the Ohio vial. The description does not give any clue as to the sizes of the different specimens, and the mixed series therefore cannot be separated again in accordance with the origin of the specimens.

Name. - Ivie dedicated his new species to Beatrice Vogel Durden. Barrows did not give any explanation of the derivation of the name ornithes, but his remarks on the female epigyne gives us a key: "The epigynum (Fig. 7A) appears as if made up of two gasteropod shells with the large openings toward the abdomen. When seen from behind the two parts appear as two bird heads placed beak to beak." The name therefore appears to refer to the two birds, revealed in a 
posterior view of the epigyne (ornis is Greek for bird, ornithes is the plural form). It is, of course, pure coincidence that durdenae, derived from the name Beatrice Vogel obtained through her marriage, has to be discarded in favor of the older ornithes, a name that still links the species with Beatrice Vogel, but now through the plural form of her maiden name (Vogel is the Dutch and German word for bird, ornithes is Greek for birds).

Distribution. - The number of available specimens has considerably increased during the years. The distribution (see map, Fig. I) now comprises, beside Pennsylvania, Tennessee and Ohio, also North Carolina, W. Virginia and Virginia. The species is probably not rare, but, in my own experience, is not easily collected because of its concealed habitat. Barrow's Ohio specimens came from "under a log in a wooded ravine" (October), Ivie's specimens from Pennsylvania were collected in July, and so was Vogel's specimen, which came from the same locality in Pennsylvania. No other data on the habitat are available from literature. I have collected a fair series ( 2 I우 $20^{x}$ ) in the Great Smoky Mountains National Park along the trail to the Alum Cave Bluffs. This trail leads off the road from Sugarlands to Newfound Gap in northern direction to Mount Le Conte, and is on the Tennessee side of the park, though close to the North Carolina line.

At the end of nearly three weeks of fruitless search for this species at both sides of the Smoky Mountains Range, we found a few specimens on what was planned to be our last day in this area. The next day we returned to the same spot and added a few more specimens to our collection. The species was found to inhabit small cavities and crevices in the steep rocky sides of the trail, and also in the dark hollows under and between the roots of trees. The forest at this height, between IIOO and I $300 \mathrm{~m}$, has a heavy undergrowth of Rhododendron spec. and Dog-hobble (Leucothoë fontanesiana). The spiders were very difficult to collect. Even when we knew where to find them, many escaped by retreating from the entrances of their little caves into dark and impenetrable depths.

The distribution, as presented in Figure $\mathrm{I}$, is based on specimens examined by myself as well as on data supplied by my colleague and friend Dr. William A. Shear. The collecting dates of the various samples range from May until October. There is only one other mention of the exact circumstances of collecting: William Shear collected Io by sweeping tall weeds near Athens in West Virginia, a situation that does not agree with the habitat described above (which may have been delimited too rigidly). 

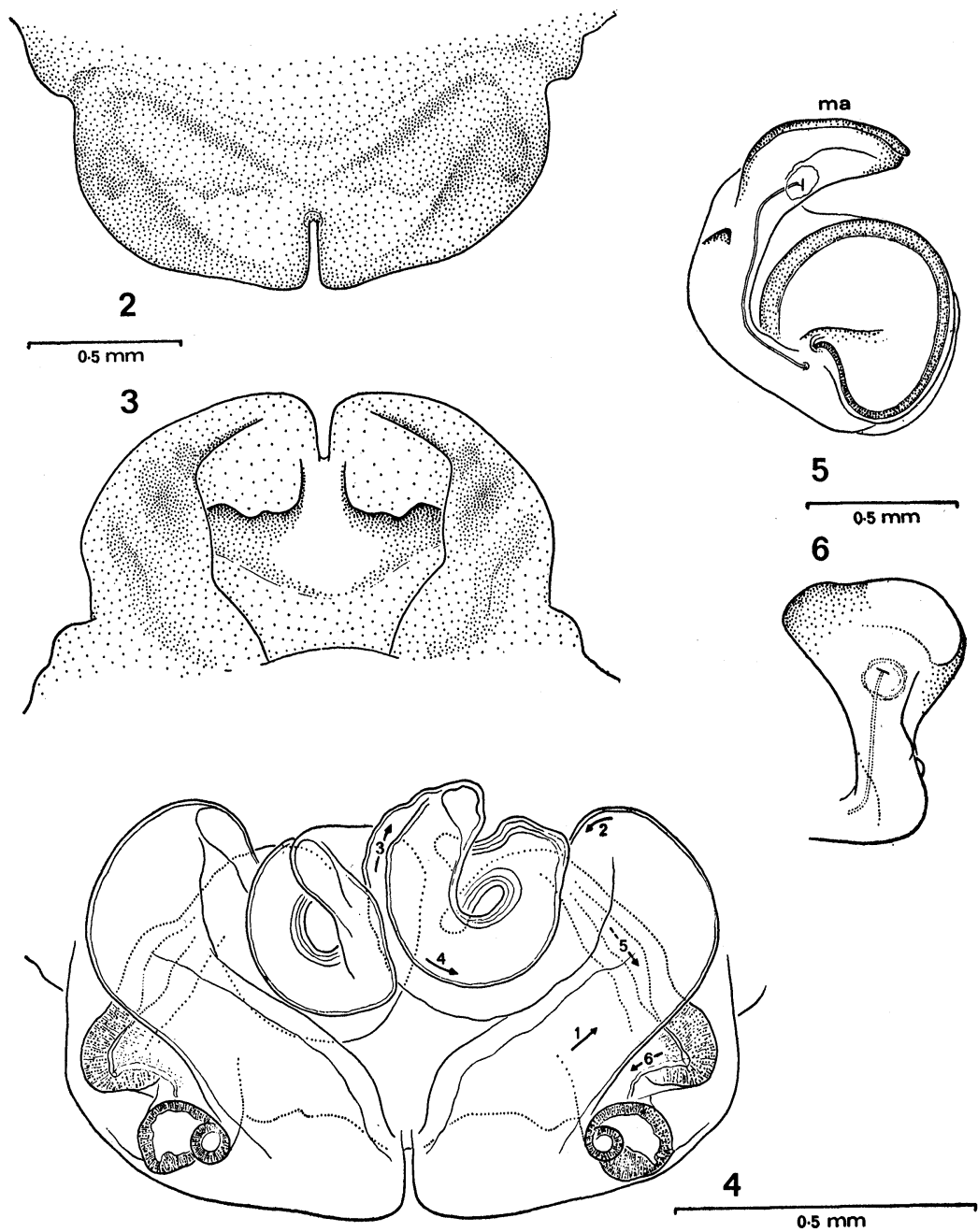

Figures 2-6. Taranucnus ornithes (Barrows). Figs. 2-3, epigyne, ventral and dorsal aspect, respectively. Fig. 4, vulva, route to be followed by embolus indicated by consecutively numbered arrows. Fig. 5, tegulum and median apophysis $(m a)$ of male palp. Fig. 6, median apophysis, dorsal aspect. 
The genus Taranucnus is represented in Europe by the type-species, T. setosus (O.P.-Cambridge), which I have collected from several localities in The Netherlands, and by $T$. bihari Fage, a troglobiontic species from Rumania, which I do not know. A diagnosis of the genus, as based on setosus and ornithes, reads as follows.

Small spiders (3.2 $\mathrm{mm}$ or less). Cephalothorax not much longer than wide. Eyes large, with PME closer to PLE than to each other. Chelicerae with stridulating files, dorsal margins with three teeth. Legs slender and very long (femur I ca. 2 times length cephalothorax, tibia I even slightly longer). Legs spinose, including femora and metatarsi. Metatarsus IV without trichobothrium, Tm I o.I50.25. Abdomen with pattern, composed of blackish bars and areas but without white pigmented spots. Male palp with a short tibia, a rather flat and broadly rounded cymbium, which has a strongly modified proximal part, and with a long, thin embolus; the embolus is supported by a well-developed embolic membrane. Epigyne with membraneous, coiled ducts leading to small receptacula; no socket or semi-covered depression visible for the reception of an apophysis of the male palp.

Both species prefer dark, protected places for a habitat: $T$. ornithes in crevices and cavities, $T$. setosus under overhanging vegetation (e.g. thick layers of heath) at the border of fens. The habitat of T. bihari would very well fit into this picture.

Taranucnus clearly fits into the tribe Linyphieae and seems very close to Labulla.

Taranucnus ornithes and T. setosus, beside their occurrence on different continents, differ from each other mainly in the genitalia. Also ornithes seems to be the smaller species with more slender legs and a slightly more proximal $\mathrm{Tm} \mathrm{I}$.

The descriptions of $T$. ornithes by Barrows and Ivie can be supplied with the following data.

Measurements (in mm). Male, total length 2.0-2.7, length cephalothorax I.O5-I.3, width 0.9-I.05. Female, total length 2.2-3.0, length cephalothorax I.05-I.2, width $0.85-\mathrm{I} . \mathrm{O}$.

Ratio length to width of cephalothorax ca. 0.85 , which is high if compared with other, related genera (cf. Linyphia 0.65-0.75, Neriene 0.55-0.75). Eyes large (diameter PME $0.09 \mathrm{~mm}$ ) and close together, the PME one-half diam. apart, and closer to each other than to PLE. AME not much smaller than PME. Chelicerae with distinct stridulating files; three teeth in dorsal and three in ventral row.

Legs very long and slender: femur I 2 times as long as cephalo- 


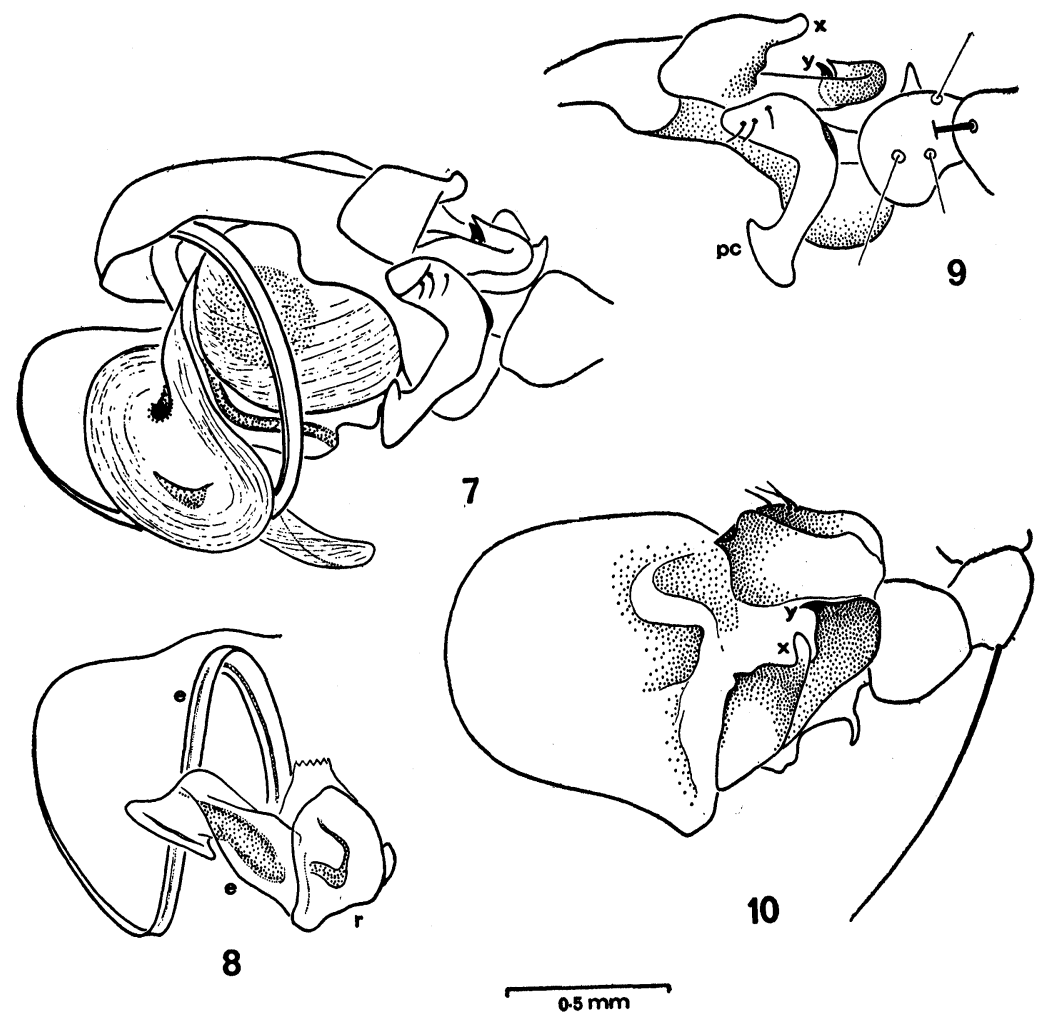

Figures 7-10. Taranucnus ornithes (Barrows), male palp. Fig. 7, lateral aspect. Fig. 8, radix $(r)$ with embolus $(e)$. Fig. 9, paracymbium $(p c)$ and basal section of cymbium, showing modifications, lateral aspect. Fig. 10 , cymbium, dorsal aspect. 
thorax $\left(\sigma^{x}\right)$ or slightly less (ㅇ), tibia I 22-24 ( $\sigma^{x}$ ) or 20-22 (ㅇ) diameters of segment long. Tibia I (without patella) slightly longer than femur, metatarsus shorter than tibia. Femora I-III with a dspine on one-fourth of length, femur I with an additional $1^{\prime}$-spine. All tibiae with the usual d-spines (basal $\mathrm{d}^{\prime \prime}$-spine ${ }^{1}$ at $0.3-0.35$ ); tibia I with a pair of $\mathrm{v}$-spines, a $\mathrm{l}^{\prime}$ and a $\mathrm{l}^{\prime \prime}$-spine, and a whorl of apical spines; tibia II with $\mathrm{a} \mathrm{v}^{\prime \prime}$ and a $\mathrm{l}^{\prime \prime}$-spine only, III and IV without ventrals or laterals, but apical spines present on all tibiae. Metatarsi all with a single d-spine on 0.20-0.25. All spines long ( 3 times diameter of segment or more) and thin. Tm I 0.I6-0.20.

Abdomen as depicted by Ivie (I966: fig. 5), characterized by the inverted heart-shaped dark grey spot dorsally, followed by chevron and cross-bars of the same colour.

The malp palp was depicted and described at some length by Ivie (I966: 224, figs. 3-4). I add the following remarks to his observations (Figs. 5-IO). Patella and tibia short and simple, the patella bearing a strong dorsal spine, the tibia with a number of hardly thickened spine-hairs. Cymbium (Figs. 9-IO) with complexly modified basal parts, but with a simple, elbow-shaped paracymbium with the tip of the free arm widened into a flat, rounded plate; cymbium proper with two sclerites, a mesal and a lateral one, which are more sclerotized than the distal part of the element, and which enclose, together with the distal part, a deep dorsal depression of the cymbium; mesal sclerite distinctly connected without seam along the sclerotized mesal brim of the cymbium, lateral sclerite apparently with membraneous connections only. Median apophysis (Figs. 5-6, $m a)$ with slender base but broadening into a flat and thin plate-like structure; no tooth or sharp tip; spermduct leaving element at the inside of the curvature. Radix (Fig. 8, $r$ ) a short, centrally situated element, spermduct running through the element and showing a dilation in the middle (Fickert's gland?). Embolus (Fig 8,e) with firm base, long and tapering to a thin, thread-like tip. Embolic membrane a flat but twisted membraneous structure with narrowly upturned brim, arising from connecting membrane between median apophysis and radix.

Epigyne (Figs. 2-3) showing at either side a chitinous roof over the entrance of the duct, mesally separated by a narrow incision. Vulva (Fig. 4) showing the spirally coiled ducts, which run in loops in anterior direction but then turn backward again toward the thick-

\footnotetext{
${ }^{1}$ As usual, the directions of the individual spines are noted by means of single or double accents, e.g. $d^{\prime}$ for pro-dorsal, $d^{\prime \prime}$ for retro-dorsal, $1^{\prime}$ for pro-lateral, $1^{\prime \prime}$ for retro-lateral, etc.
} 
walled portions close to the receptacula, the latter situated against the posterior wall at the outside of the entrances. Receptacula small.

It is clear that the embolus is supported by the embolic membrane in the unexpanded palp, and it is not unlikely that it also guides and supports the long embolus during the difficult process of introducing the long and flexible element into the vulva. The whole palp may find firm support against the epigyne by means of the intricate dorsal modification of the cymbium. The median apophysis does not show any hook-shaped parts (cf. Linyphia, Neriene, etc.) and, at the most, may serve the purpose of supporting the functioning palp during copulation by being pressed with its broad and flattened apical portion against the epigyne. The embolus of $T$. ornithes does not have the small, toothed apophysis at the base of the embolus as shown in the figures of $T$. setosus by Merrett (1963: 382, fig. 39).

\section{Oreonetides recurvatus (Emerton, I913)}

Figures I, I I-I 7

Bathyphantes recurvatus Emerton, 1913, Trans. Connecticut Acad. Arts Sci., 18: 218, pl. 2 fig. 8 (descr. $\hat{o}$, Vermont). - Ivie, 1969, Amer. Mus. Novit., 2364: 7 (=Orconetides $r$.).

Aigola recurvata; Crosby, 1937, Proc. Biol. Soc. Washington, 50: 40, pl. 1 fig. 10 (descr. $\hat{o}$, New York).

Troglohyphantes kokoko Ivie, 1966, J. New York Ent. Soc., 74: 226, figs. 6-7 (descr. \&, Ontario; New York). NEW SYNONYMY.

Types. - $\sigma^{7}$ holotype of Bathyphantes recurvatus from Gore Mountain, Norton, Vermont, in MCZ (examined). + holotype and o paratype of Troglohyphantes kokoko from Ko-ko-ko Bay, Lake Timagami, Ontario, reported to be in the AMNH (not seen).

Additional material. - The specimens from Mt. Whiteface, New York, mentioned by Crosby (1937) have been examined in the AMNH. More recently collected specimens (It $30^{x}$ ) come from George Lake, Alberta, Canada (CNC), 20.IX-I.X.I966 (Fig. I).

Oreonetides recurvatus is a small species with long, slender legs, which are well provided with spines on femora, tibiae, and metatarsi. 'Tibia I has, beside the dorsal spines, a $\mathrm{l}^{\prime}$, a $\mathrm{l}^{\prime \prime}$ and $2 \mathrm{v}$-spines. The chelicerae have three teeth in the dorsal row. The abdomen shows a dorsal pattern of grey cross-bars. Taking all together, it is not very likely that the present species belongs to Oreonetides, but it is maintained there for the time being. The genus is due for revision, and it does not seem appropriate to create a new genus for recurvatus here without having studied the other species presently residing in Oreonetides. 


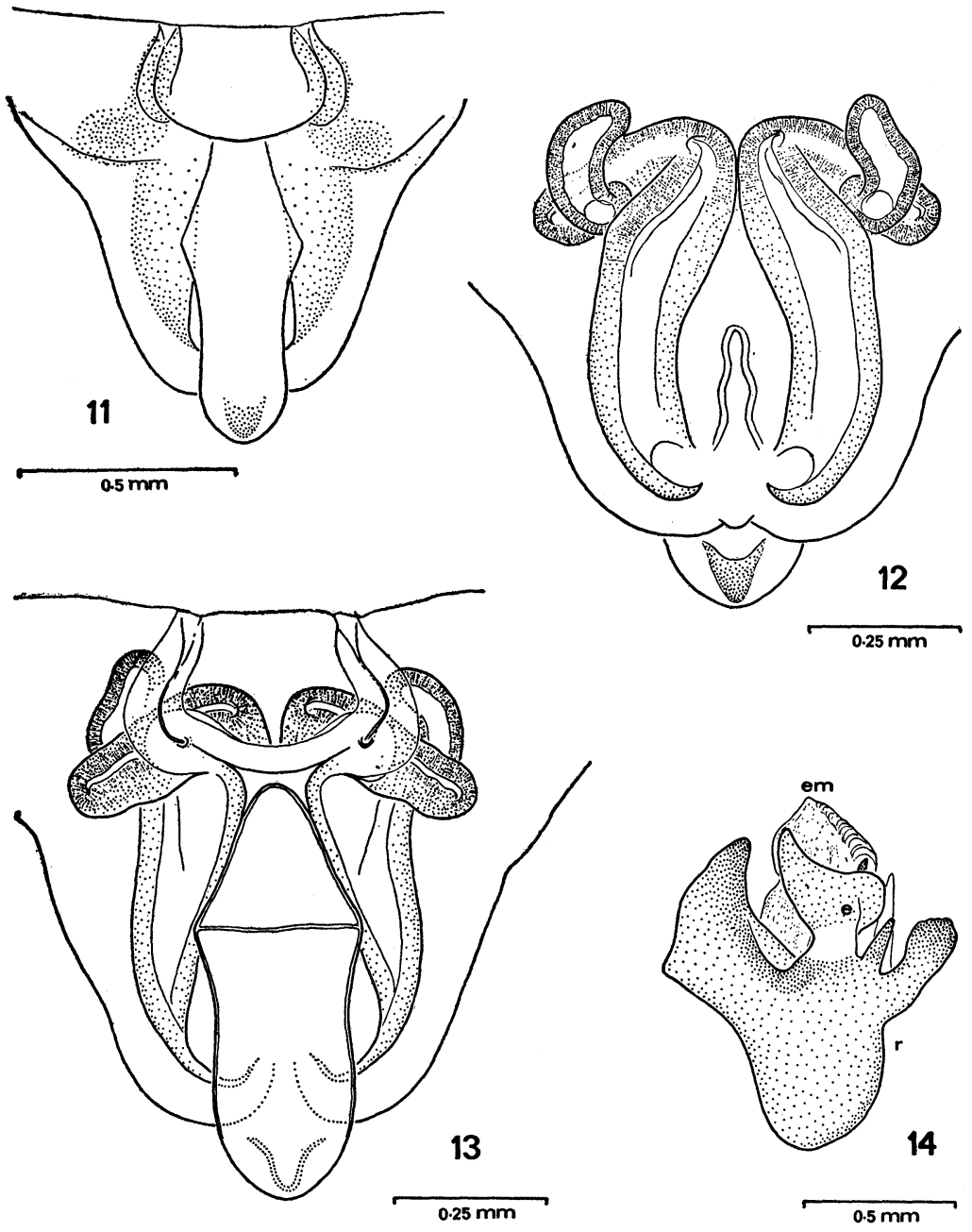

Figures 11-14. Oreonetides recurvatus (Emerton). Fig. 11, epigyne, dorsal aspect. Figs. 12-13, vulva, ventral (12) and dorsal (13) aspects. Fig. 14, radix $(r)$, embolus $(e)$ and embolic membrane (em) of male palp, mesal aspect. 
A first attempt to revise Oreonetides has been published recently (Saaristo, 1972). The paper contains a good characterization with excellent figures of the type-species, $O$. vaginatus (Thorell), but the many other, mostly Nearctic, species are not included. The diagnosis of the genus, therefore, might be too narrow to fit the other species, though it very well may be necessary to divide the genus into a number of smaller units. The creation of Montitextrix by Denis (1963) for O. glacialis (L. Koch) was a first step in that direction. Oreonetides flavus (Emerton) and O. rotundus (Emerton), both from the Nearctic region, are very close to $M$. glacialis in their genital structures, but differ in the positions of the Tm I (0.65-0.70 in glacialis, $0.30-0.40$ in flavus and rotundus) and the presence of a trichobothrium on metatarsus IV in glacialis (absent in all others).

A few species are more closely related to - i.e. more closely resemble - the type-species vaginatus, viz., filicatus, firmus and abnor$m i s$, and possibly also rectangulatus. I do not see the principal difference between vaginatus on the one hand, and firmus and abnormis on the other (cf. Saaristo, 1972: 70). Oreonetides might constitute an example of transition from the still folded scapes (but how under-developed in comparison with the flexible and elaborately built scapes of Lepthyphantes species!) of vaginatus and filicatus to the rigid and unfolded scape of firmus and abnormis, where the narrow portion of the scape with the socket or semi-covered depression is not present. The absence of a well-developed median apophysis (Saaristo: suprategulum) is, of course, correlated with this simple build of the epigyne, and should not be used as an independent character.

Oreonetides filicatus is a good species and not a synonym of vaginatus as suggested by Saaristo (1972: 72). It is smaller than vaginatus, but both male palp and epigyne are resembling each other, though they differ in detail. Without question the species is congeneric with vaginatus. However, the anterior tibia does not bear the $\mathrm{l}^{\prime}$-spine, which is one of the characters mentioned in the diagnosis of the genus by Saaristo (1972: 69). I put this forward here as a demonstration of my above remark on the too narrow delimination of the genus.

Oreonetides rectangulatus (Emerton), of which I only know the male, is different in several respects. Most striking are the peculiarly shaped chelicerae, which bear a strong conical protrusion on their dorsal surface for three-fifths of their length. The palp also deviates from the true Oreonetides type.

Oreonetides Alavescens (Crosby), described in Aigola (Crosby, 1937: 39, figs. 7-8) from New York I have not seen, but judging 


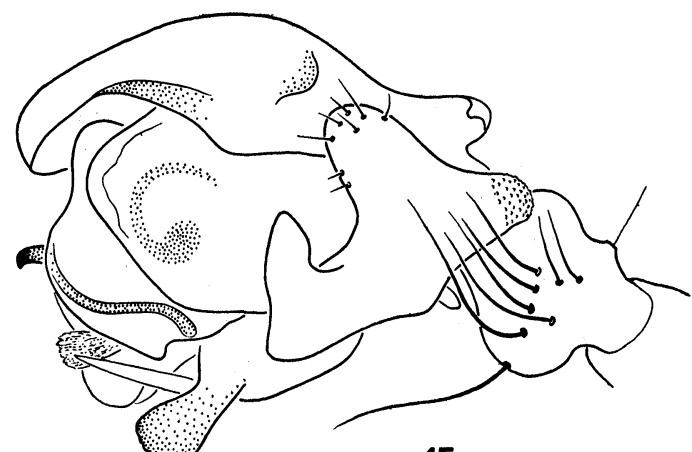

15
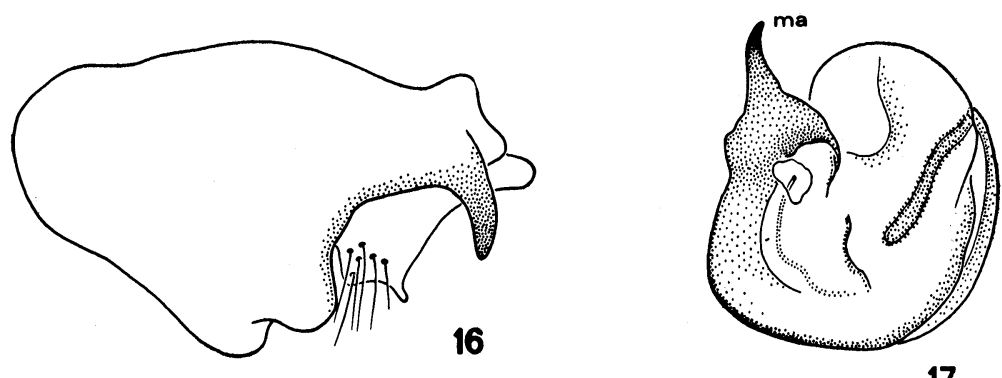

$0.5 \mathrm{~mm}$

Figures 15-17. Oreonetides recurvatus (Emerton), male palp. Fig. 15, lateral aspect. Fig. 16, cymbium, dorsal aspect. Fig. 17, tegulum with median apophysis $(m a)$. 
from the figures and description it was correctly placed with vaginatus and related species.

To the descriptions of $O$. recurvatus given by the various authors $\mathrm{I}$ add the following remarks.

Measurements (in mm). Male, total length 2.7-3.0, length cephalothorax I.25-I.43, width I.05-I.2O. Female, total length 2.7 (Ivie, I966: $2.8 \mathrm{~mm}$ ), length cephalothorax I.22 (I.3), width I.O5 (I.I).

Ratio length to width of cephalothorax 0.85. PME large (o.09 $\mathrm{mm}$ ), separated by their diameter, same distance to AME which are barely smaller; lateral eyes of posterior and anterior rows contiguous. Chelicerae showing sexual dimorphism; $\sigma^{7}$ with three "teeth" on dorsal margin: a basal, round tubercle with a more slender and sharp tooth just dorsally of its tip, a second tooth at some distance of the basal tubercle, and with a small tubercle at the end of the row; ventral row with two small teeth; o also with three dorsal "teeth", ventral row with five small teeth (three ventral teeth according to Ivie, I966). Stridulating files well-developed, ridges fine and close together.

Legs long and slender, femur I I.8-1.9 times length cephalothorax, tibia I 20-23 ( $\left.\sigma^{4}\right)$ or I8 (ㅇ) diams. of segment long. Tibia I longer than femur I, metatarsus as long as femur $\left(\sigma^{\lambda}\right)$ or slightly shorter (ㅇ). Femora I-III with a d-spine (on 0.5 ), femur I with an additional 1 '-spine. All tibiae with $2 \mathrm{~d}$-spines (position basalmost $\mathrm{d}$ spine $0.25-0.35$ ), tibia I also with one $1^{\prime}$, one $\mathrm{l}^{\prime \prime}$, and $2 \mathrm{v}$-spines, tibia II with one v-spine and a $1^{\prime \prime}$-spine; apical spines on segments hardly developed; all metatarsi with a single d-spine (position ca. 0.20 ). Tm I o.I 5-0.20, metatarsus IV without trichobothrium.

Male palp (Figs. I4-I7). Characteristic is the meso-proximal hook-like projection of the cymbium, which points laterad (Fig. I6). The paracymbium lacks the isolated ventral hair which occurs in $O$. vaginatus (see Saaristo, 1972), and also in $O$. filicatus and rotundus; only a small tubercle present on this spot. Median apophysis (Fig. I7, ma) well-developed, with slightly curved tip. Embolic section (Fig. I4) in general structure resembling vaginatus, but without lamella; ventro-lateral branch rounded-truncated, a slender, chitinous projection present between this branch and base of embolus, and a second, equally narrow, slightly larger, membraneous projection, arising from the dorsal surface of the radix. Embolus $(e)$ short and squat, curved, with a sharp spermduct tooth, and well-protected by the embolic membrane $(\mathrm{em})$, which arises from the dorsal surface of the radix from the membraneous connection between median apophysis and radix $(r)$. 
Epigyne and vulva (Figs. II-13). Epigyne as depicted by Ivie (1966: figs. 6-7). Scape folded and reappearing from below the main body of the scape with a rounded, membraneous tongue, which possesses a semi-covered depression. Entrances of ducts situated in the main body of the epigyne, laterally and behind the bend of the scape; ducts converging in forward direction, then curving outwards to turning-points and to the receptacula seminis, which lie close to the turning-points. The short fertilization-ducts curving to dorsal side and ending as open gutters.

From the structures of palp and epigyne it is clear that the median apophysis, in connection with the depression at the tip of the scape, serves as an important means of support during copulation. The scape of the epigyne looks rather rigid and probably cannot be pulled out of its resting position very far (cf. Lepthyphantes), though the ventralmost part may get pushed away from the main body so as to allow the embolus to reach the entrance of the duct of the epigyne. The exact functions of the hook-like projection of the cymbium, the proximal, roughened extension of the paracymbium, and the lateral arm of the radix are not easily understood without the aid of actual observation of the pairing in one of the species of this group.

\section{AcKNowledgements}

The present study is part of a general survey of North American Linyphiidae, supported by Public Health Service Research Grant AI-o 1944, from the National Institute of Allergy and Infectious Diseases, to H. W. Levi.

The help with types and other specimens by the following institutions and their curators is thankfully acknowledged: Dr. Herbert W. Levi, Museum of Comparative Zoology, Harvard University, Cambridge, U.S.A. (MCZ); Dr. John A. L. Cooke, American Museum of Natural History, New York (AMNH); Dr. C. A. Triplehorn, Ohio State University, Columbus, Ohio; Dr. Robin E. Leech, Canadian National Collection, Ottawa, Canada (CNC). Thanks are also due to Dr. William A. Shear, Concord College, Athens, W. Virginia, for information on his collection.

\section{REFERENCES}

Barrows, W. M.

1940. New and rare spiders from the Great Smoky Mountains National Park region. Ohio J. Sci., 40: 130-138, figs. 1-12.

Crosby, C. R.

1937. Studies in American spiders: the genus Aigola Chamberlin. Proc. Biol. Soc. Washington, 50 : 35-42, pl. 1. 
Denis, J.

1963. Araignées des Dolomites. Atti Ist. Veneto Sci. Lett. Arti, 121: 253-271, figs. 1-16.

EMERToN, J. H.

1913. New England spiders identified since 1910. Trans. Connecticut Acad. Arts Sci., 18 : 209-224, pls. 1-2.

IvIE, W.

1966. Two new North American spiders (Araneae: Linyphiidae). J. New York Ent. Soc., 74: 224-227, figs. 1-7.

1969. North American spiders of the genus Bathyphantes (Araneae, Linyphiidae). Amer. Mus. Novit., 2364 : 1-70, figs. 1-121.

Merrett, $P$.

1963. The palpus of male spiders of the family Linyphiidae. Proc. Zool. Soc. London, 140 : 347-467, figs. 1-127.

SAARISTO, M. I.

1972. Redelimitation of the genus Oreonetides Strand, 1901 (Araneae, Linyphiidae) based on an analysis of the genital organs. Ann. Zool. Fennici, 9: 69-74, figs. 1-17.

VOGEL, B. R.

1967. A list of new North American spiders (1940-1966). Mem. Amer. Ent. Soc., 23 : 1-186.

1968. Additional records of spiders from Western Pennsylvania. J. New York Ent. Soc., 76 : 101-105. 

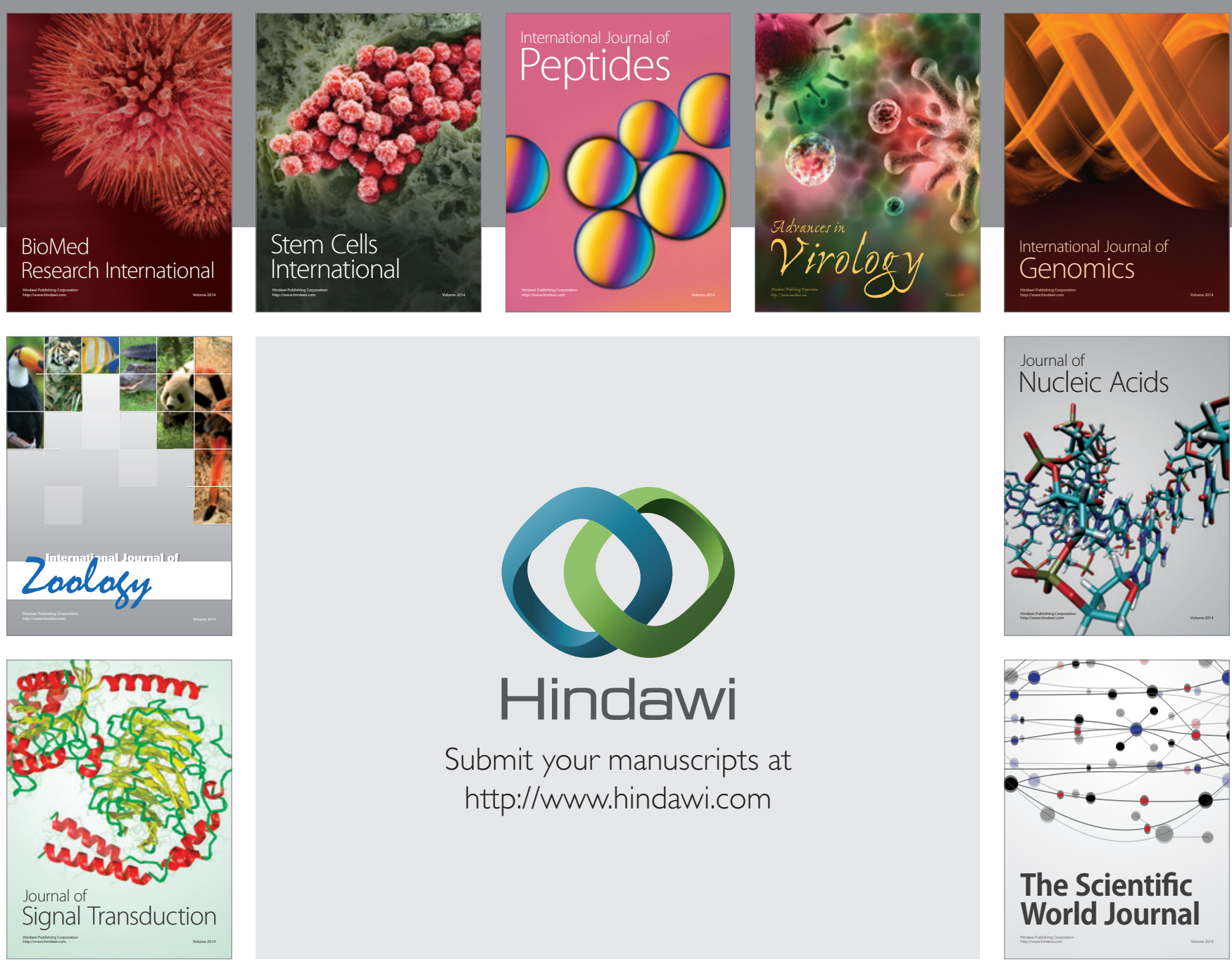

Submit your manuscripts at

http://www.hindawi.com
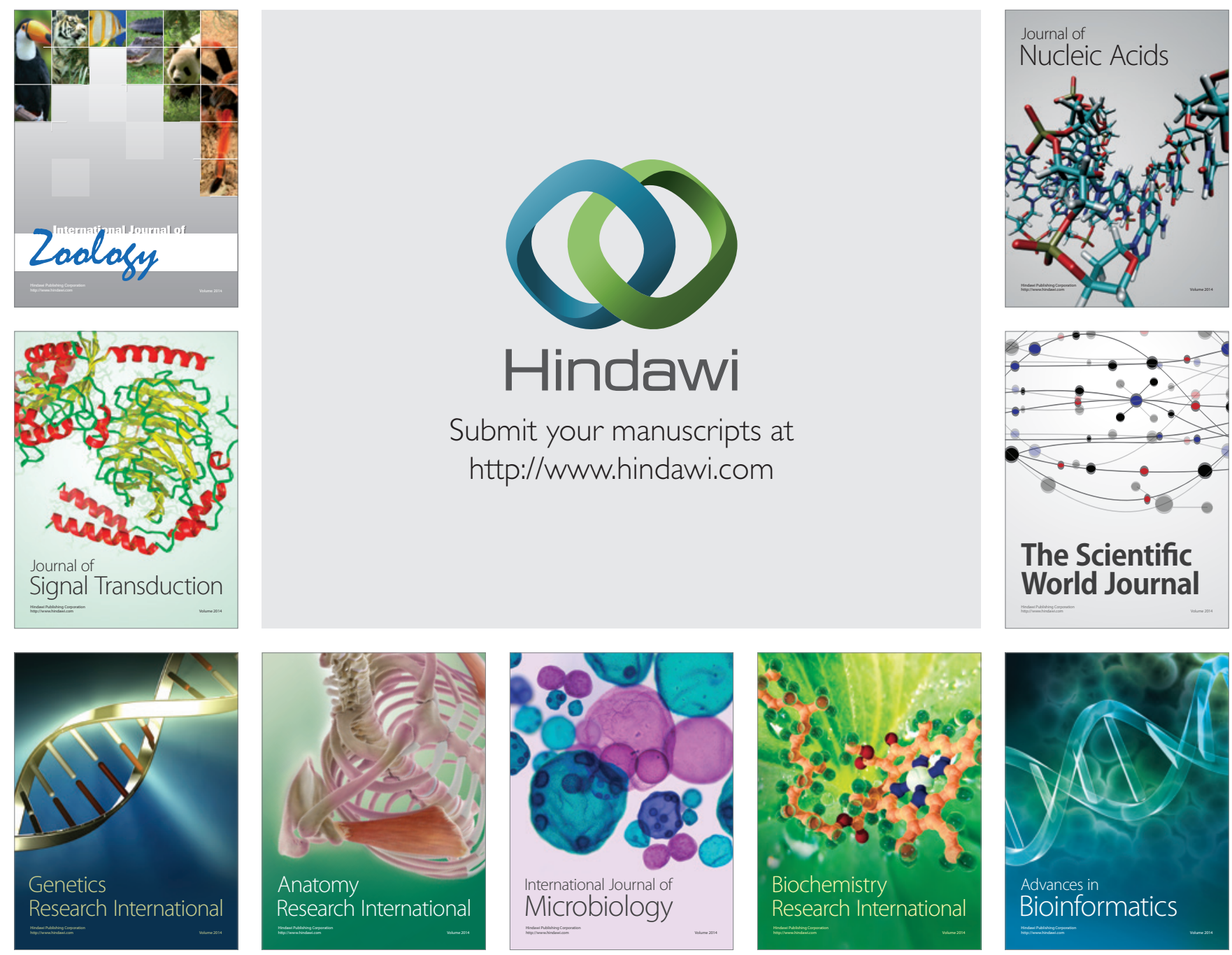

The Scientific World Journal
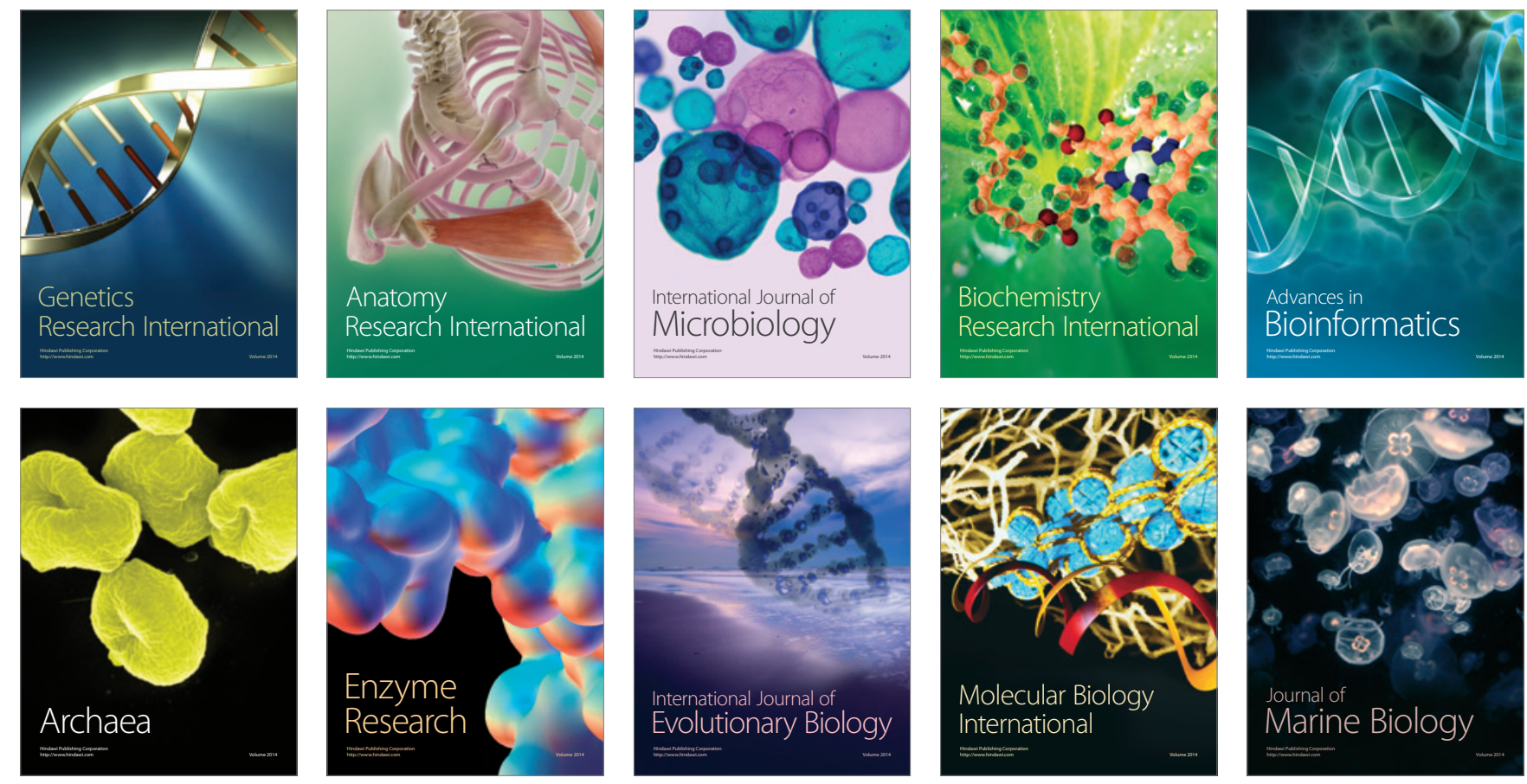